\title{
Correction to: Molecular signature comprising 11 platelet-genes enables accurate blood-based diagnosis of NSCLC
}

Chitrita Goswami ${ }^{1 \dagger}$, Smriti Chawla ${ }^{2 \dagger}$, Deepshi Thakral ${ }^{3}$, Himanshu Pant ${ }^{4}$, Pramod Verma ${ }^{3}$, Prabhat Singh Malik ${ }^{5}$, Jayadeva ${ }^{4}$, Ritu Gupta ${ }^{3 *}$, Gaurav Ahuja ${ }^{2^{*}}$ and Debarka Sengupta ${ }^{1,2,6,7^{*}}$

\section{Correction to: BMC Genomics 21, 744 (2020) \\ https://doi.org/10.1186/s12864-020-07147-z}

Following the publication of the original article [1], it was reported that Ritu Gupta was not listed as a corresponding author in the online version of the article. The original article has been corrected.

\begin{abstract}
Author details
'Department of Computer Science and Engineering, Indraprastha Institute of Information Technology, New Delhi, India. ${ }^{2}$ Department of Computational Biology, Indraprastha Institute of Information Technology, New Delhi, India. ${ }^{3}$ Laboratory Oncology Unit, All India Institute of Medical Sciences, New Delhi, India. ${ }^{4}$ Department of Electrical Engineering, Indian Institute of Technology, New Delhi, India. ${ }^{5}$ Department of Medical Oncology, All India Institute of Medical Sciences, New Delhi, India. Institute of Health and Biomedical Innovation, Queensland University of Technology, Brisbane, Australia. ${ }^{7}$ Centre for Artificial Intelligence, Indraprastha Institute of Information Technology, New Delhi, India.
\end{abstract}

Published online: 08 December 2020

\section{Reference}

1. Goswami C, Chawla S, Thakral D, et al. Molecular signature comprising 11

platelet-genes enables accurate blood-based diagnosis of NSCLC. BMC

Genomics. 2020;21:744 https://doi.org/10.1186/s12864-020-07147-z.

The original article can be found online at https://doi.org/10.1186/s12864 020-07147-z.

*Correspondence: drritugupta@gmail.com; gaurav.ahuja@iiitd.ac.in; debarka@iiitd.ac.in

${ }^{\dagger}$ Chitrita Goswami and Smriti Chawla contributed equally to this work.

${ }^{3}$ Laboratory Oncology Unit, All India Institute of Medical Sciences, New Delhi, India

${ }^{2}$ Department of Computational Biology, Indraprastha Institute of Information Technology, New Delhi, India

'Department of Computer Science and Engineering, Indraprastha Institute of Information Technology, New Delhi, India

Full list of author information is available at the end of the article

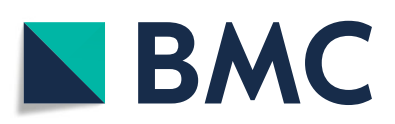

() The Author(s). 2020 Open Access This article is licensed under a Creative Commons Attribution 4.0 International License, which permits use, sharing, adaptation, distribution and reproduction in any medium or format, as long as you give appropriate credit to the original author(s) and the source, provide a link to the Creative Commons licence, and indicate if changes were made. The images or other third party material in this article are included in the article's Creative Commons licence, unless indicated otherwise in a credit line to the material. If material is not included in the article's Creative Commons licence and your intended use is not permitted by statutory regulation or exceeds the permitted use, you will need to obtain permission directly from the copyright holder. To view a copy of this licence, visit http://creativecommons.org/licenses/by/4.0/. The Creative Commons Public Domain Dedication waiver (http://creativecommons.org/publicdomain/zero/1.0/) applies to the data made available in this article, unless otherwise stated in a credit line to the data. 